\title{
KEBERADAAN JENTIK DAN PERILAKU PSN TERHADAP KEJADIAN DBD (STUDI PADA WILAYAH KERJA PUSKESMAS CANDI TAHUN 2019)
}

Fernanda Fitriani Iskandar, Ferry Kriswandana, Rusmiati

Jurusan Kesehatan Lingkungan Poltekkes Kemenkes Surabaya Email: ferry.kesling@gmail.com

\begin{abstract}
ABSTRAK
Demam berdarah merupakan penyakit yang disebabkan oleh infeksi virus dengue yang ditularkan melalui gigitan nyamuk Aedes dan telah menyebar di daerah tropis khususnya Indonesia. Salah satu faktor meningkatnya kasus penyakit demam beradarah dengue ialah faktor kondisi lingkungan sekitar dan perilaku PSN. Tujuan dari penelitian ini ialah menganalisis hubungan antara kondisi lingkungan dengan perilaku PSN terhadap kejadian demam berdarah dengue di wilayah kerja Puskesmas Candi Kecamatan Candi Kabupaten Sidoarjo.

Metode yang digunakan case control dengan menggunakan teknik pengambilan sampel simple random sampling dan sampel yang digunakan sebanyak 60 rumah. Pengumpulan data dilakukan dengan cara observasi dan penyebaran kuisioner pada responden. Analisa data menggunakan uji chi-square.

Hasil penelitian menunjukkan bahwa perilaku PSN masyarakat cukup, tetapi ditemukannya keberadaan jentik 33,3\% di 20 rumah dengan nilai $p>0,028$ menyatakan ada hubungan antara keberadan jentik dengan kejadian DBD Perilaku PSN yang meliputi pengetahuan $(p<0,031)$, sikap $(p>0,347)$ dan tindakan $(p<0,02)$. Artinya, pengetahuan dan tindakan responden memiliki hubungan bermakna dengan kejadian DBD. Sedangkan, sikap responden tidak memiliki hubungan bermakna dengan kejadian DBD. Selain itu, Perilaku PSN $(p>0,037)$ memiliki hubungan yang bermakna dengan kejadian DBD.

Dari hasil penelitian bahwa perilaku PSN yang baik dapat mengurangi keberadaan jentik penular DBD. Dengan demikian dapat disarankan kepada masyarakat untuk melakukan upaya PSN terhadap kejadian DBD.
\end{abstract}

Kata Kunci: Keberadaan Jentik, Perilaku PSN, Demam Berdarah Dengue

\section{PENDAHULUAN}

Indonesia merupakan negara maritim beriklim tropis yang terletak di antara dua benua yaitu Benua Australia dan Benua Asia serta dua samudra yaitu Samudra Hindia dan Samudra Pasifik yang kaya akan flora dan fauna termasuk mempunyai berbagai penyakit menular seperti, semam berdarah dengue, malaria, Lymfatik, filariasis, chikungunya, dan Japanese encephalitis. Memasuki era milenial yang ke 3, Indonesia menghadapi berbagai perubahan dan tantangan salah satunya penyakit Demam Berdarah Dengue yang telah menyebar ke seluruh penjuru nasional dan juga belum ditemukan obat vaksin untuk mencegah penyakit tersebut.

Demam Berdarah atau yang sering disebut dengan Demam Berdarah Dengue (DBD) merupakan penyakit yang disebabkan karena virus Dengue yang memiliki 4 serotipe yaitu DEN 1, DEN 2, DEN 3 dan DEN 4. Virus tersebut ditularkan oleh nyamuk betina dari spesies Aedes aegypti dan Aedes albopictus (Sucipto, 2018). Selain itu, tingginya kasus DBD di Indonesia sangat berkaitan dengan kondisi lingkungan yang dapat memengaruhi perkembangbiakkan nyamuk Aedes aegypti seperti Tempat Penampungan Air (TPA). Apalagi tindakan/praktek Pemberantasan Sarang Nyamuk (PSN) masyarakat yang kurang sehingga perlu diperhatikan dalam mencegah penyakit DBD (Andi Anwar, Ade Rahmat 2015).

Demam berdarah tersebar diberbagai negara tropis dan sub tropis. Data dari WHO (World Health Organization) menunjukkan Asia menempati urutan 
pertama dalam jumlah penderita DBD setiap tahunnya. Terhitung sejak tahun 1968 hingga tahun 2009 bahwa Indonesia sebagai negara dengan kasus DBD tertinggi di Asia Tenggara. Di Indonesia pertama kali ditemukan kasus DBD ditemukan di Kota Surabaya sebanyak 58 orang dan 24 orang diantaranya meninggal dunia. Dan saat itu penyakit ini menyebar luas ke seluruh Indonesia sehingga meningkatnya jumlah penderita penyebab demam berdarah. Penyebab tingginya kasus DBD di Indonesia yaitu meningkatnya mobilitas dan kepadatan penduduk (Kementerian Kesehatan, 2010).

Berdasarkan wawancara kepada petugas puskesmas menyatakan bahwa kurangnya peran serta masyarakat melakukan PSN seperti melakukan 3M Plus dan tidak meratanya Program Juru Pemantau Jentik (Jumantik) serta kurangnya penyuluhan tentang DBD. Sehingga dapat digambarkan bahwa perilaku masyarakat kurang memperhatikan kebersihan lingkungan dan belum melakukan pencegahan serta pemberantasan sarang nyamuk dengan mengendalikan vektor nyamuk Aedes aegypti. Tujuan penelitian ini adalah mengetahui hubungan keberadaan jentik dan perilaku PSN terhadap kejadian DBD.

\section{METODE PENELITIAN}

Jenis penelitian ini menggunakan penelitian analitik observasional dengan pendekatan case control. Penelitian ini dilakukan di wilayah kerja Puskesmas Candi Kecamatan Candi Kabupaten Sidoarjo. Populasi yang digunakan yaitu jumlah penderita DBD Tahun 2018 di Wilayah Kerja Puskesmas Candi sebanyak 33 rumah. Sedangkan sampel yang digunakan dalam penelitian ini adalah 30 rumah. Dengan perbandingan kasus dan kontrol adalah $1: 1$, maka total besar sampel yang digunakan dalam penelitian sebanyak 60 rumah.

\section{HASIL DAN PEMBAHASAN}

Tabel 1

KEBERADAAN JENTIK DAN KEJADIAN DBD DI WILAYAH KERJA PUSKESMAS CANDI

\begin{tabular}{ccccc}
\hline \multirow{2}{*}{ Keberadaan } & \multicolumn{2}{c}{ Jumlah } & \multirow{2}{*}{ Total } & \multirow{2}{*}{ Persentase } \\
\cline { 2 - 4 } & Kasus & Kontrol & & \\
\hline Positif & 14 & 6 & 20 & $33,33 \%$ \\
\hline Negatif & 16 & 24 & 40 & $66,67 \%$ \\
\hline Total & 30 & 30 & 60 & $100 \%$ \\
\hline
\end{tabular}

Berdasarlan tabel 1 didapatkan hasil 60 rumah yang diperiksa sebagian besar positif keberadaan jentik di 20 rumah responden $(33,33 \%)$. Sedangkan negatif keberadaan jentik sebesar 40 responden $(66,67 \%)$.

Tempat penampungan air yang dijadikan tempat perindukan nyamuk dibagi menjadi 3 yaitu tempat penampungan air yang digunakan seharihari seperti bak mandi, drum, ember dan lain lain, tempat penampungan air bukan untuk keperluan sehari-hari seperti vas bunga, ban bekas, kaleng bekas dan lainlain, dan tempat penampungan air alamiah seperti lubang pohon, tempurung kelapa, pelapah pisang dan lain-lain (Depkes RI, 2005). Pada penelitian ini melakukan pemeriksaan jentik nyamuk yang dilakukan pada saat penelitian yaitu menggunakan metode secara visual dengan melihatnya ada atau tidaknya jentik nyamuk di tempat penampungan air dan tanpa mengambil jentiknya.

Penelitian yang telah dilakukan didapatkan hasil 20 rumah positif keberadaan jentik dari 60 rumah yang diperiksa. Jenis tempat penampungan air yang positif keberadaan jentik adalah tempat penampungan air yang digunakan sehari-hari seperti bak mandi, ember, gentong dan drum.

Berdasarkan analisis bivariat dengan menggunakan uji Chi-square diperoleh nilai $p$-value sebesar 0,028 dimana $(p<0,05)$ sehingga dapat diartikan bahwa terdapat hubungan antara keberadaan jentik dengan kejadian DBD di Wilayah Kerja 
Puskesmas Candi. Hal tersebut sejalan dengan penilitian Hikmawan Suryanto tahun 2018 dan Sri Purwaningrum bahwa terdapat hubungan yang bermakna antara keberadaan jentik dengan kejadian DBD.

Tabel 2

PERILAKU PSN DENGAN KEJADIAN DBD DI WILAYAH KERJA PUSKESMAS CANDI

\begin{tabular}{cccccccc}
\hline Perilaku & \multicolumn{4}{c}{ Jumlah } & \multicolumn{2}{c}{ Total } & $\begin{array}{c}\mathbf{p} \\
\text { value }\end{array}$ \\
\hline & \multicolumn{2}{c}{ Kasus } & \multicolumn{2}{c}{ Kontrol } & & & \\
\hline & $\mathbf{N}$ & $\mathbf{\%}$ & $\mathbf{n}$ & $\mathbf{\%}$ & $\mathbf{N}$ & $\mathbf{\%}$ & 0,037 \\
\hline Cukup & 26 & 86,7 & 19 & 63,3 & 45 & 75 & \\
\hline Baik & 4 & 13,3 & 11 & 36,7 & 15 & 25 & \\
\hline Total & 30 & 100 & 30 & 100 & 60 & 100 & \\
\hline
\end{tabular}

Dari uji statistik dengan $(0,05)$ sehingga dapat diartikan terdapat menggunakan uji analisis Chi-Square hubungan yang bermakna antara dapat diperoleh hasil sebesar ( $p$ value) sebesar 0,037 dimana nilai $p$ value $<\mathrm{a}$

\section{Hubungan Pengetahuan PSN dengan Kejadian DBD}

Pengetahuan merupakan hasil tahu setelah melakukan pengindraan terhadap objek yang dimilikinya (mata, hidung, telinga dan sebagainya). Namun sebagian besar pengetahuan seseorang diperoleh melalui indra pendengaran dan penglihatan (Notoatmodjo,2014).

Berdasarkan analisis bivariat dengan menggunakan uji Chi-square diperoleh nilai $p$-value sebesar 0,037 dimana $(p<0,05)$ sehingga dapat diartikan bahwa terdapat hubungan antara pengetahuan dengan kejadian DBD. Hal tersebut sejalan dengan penelitian hikmawan suryanto tahun 2018 dengan hasil $p=$ $0,004 \quad(p<0,05)$ dimana terdapat hubungan antara pengetahuan responden dengan kejadian DBD di Kecamatan Dringu Kabupaten Probolinggo.

Sebagian besar responden belum mengerti ciri-ciri nyamuk penular $\mathrm{DBD}$, responden menjawab dengan benar dengan penyataan badan nyamuk berbelang warna hitam dan putih pada seluruh tubuhnya hanya sebesar $12 \%$. Selain itu, pengetahuan responden juga kurang mengenai tempat perindukkan nyamuk. Responden yang kurang mengetahui bahwa nyamuk penular DBD berkembang biak pada tempat yang tidak kontak langsung dengan tanah. Dengan kurangnya pengetahuan responden pada perilaku PSN dengan kejadian DBD di wilayah kerja Puskesmas Candi.

beberapa aspek dapat membahayakan karena tidak tahu atau mengerti ciri-ciri nyamuk DBD dan tempat perindukkan nyamuk DBD.

\section{Hubungan Sikap PSN dengan Kejadian DBD}

Sikap merupakan reaksi atau respon yang masih tertutup dari seseorang terhadap suatu stimulus atau objek. Manifestasi dari sikap tidak dapat langsung dilihat sehingga suatu sikap belum otomatis terwujud dalam suatu tindakan. Namun, sikap dapat menjadi salah satu faktor yang mendukung kecenderungan seseorang untuk bertindak. (Notoatmodjo, 2014)

Berdasarkan analisis bivariat dengan menggunakan uji Chi-square diperoleh nilai $p$-value sebesar 0,347 dimana $(p<0,05)$ sehingga dapat diartikan bahwa tidak ada hubungan antara sikap dengan kejadian DBD. Hal tersebut sejalan dengan penelitian Yayang Hidayatul $\mathrm{N}$ tahun 2018 dengan hasil $p=0,083$ $(p<0,05)$ dimana tidak ada hubungan antara sikap responden dengan kejadian DBD di wilayah kerja Puskesmas Papar.

Sikap dinilai dengan tanggapan setuju atau tidak setuju dengan bentuk pertanyaan mendukung atau tidak mendukung. Dari pernyataan yang diberikan, terdapat sebesar $77 \%$ responden menganggap bahwa penyakit DBD bukan tanggungjawab pemerintah, melainkan tanggung jawab masyarakat 
dalam mengelola lingkungannya. Sedangkan yang membuat keberadaan jentik berada didalam rumah merupakan tanggung jawab perilaku penghuni tersebut. Karena hak milik dari isi rumah tersebut merupakan kepemilikkan penghuni.

\section{Hubungan Tindakan PSN dengan Kejadian DBD}

Tindakan yang baik didasar dengan adanya pengetahuan yang cukup baik dan sikap yang baik (Respati, 2006). Setelah seseorang mengetahui stimulus atau obyek kesehatan, kemudian mengadakan penilaian terhadap apa yang diketahui, proses selanjutnya diharapkan ia akan melaksanakan atau mempraktekkan apa yang disikapinya nilai baik (Notoatmodjo, 2003).

Berdasarkan analisis bivariat dengan menggunakan uji Chi-square diperoleh nilai $p$-value sebesar 0,002 dimana $(p<0,05)$ sehingga dapat diartikan bahwa terdapat hubungan antara tindakan dengan kejadian DBD. Hal tersebut sejalan dengan penelitian Yayang Hidayatul $\mathrm{N}$ tahun 2018 dengan hasil $\mathrm{p}=$ $0,011 \quad(p<0,05)$ dimana terdapat hubungan antara tindakan responden dengan kejadian DBD di wilayah kerja Puskesmas Papar.

Sebagaian besar responden tidak menanamkan pengusir nyamuk disekitar rumah yang disebabkan karena batasan lahan. Tanaman yang dapat dijadikan sebagai pengusir nyamuk yaitu lavender, kantong semar, sereh, geranium danlain. Selain itu, sebagian responden tidak melakukan pengurasan bak mandi dengan diselingi penyikatan dinding bak mandi. Hal ini dilakukan karena kebiasaan nyamuk meletakkan telurnya diatas permukaan air dan dapat dirontokan dengan cara penyikatan dinding.

\section{Hubungan Perilaku PSN dengan Kejadian DBD}

Perilaku PSN merupakan perilaku masyarakat dalam kaitannya memberantasa sarang nyamuk penular DBD, akan tetapi perilaku seseorang sangat kompleks dan mempunyai bentangan yang sangat luas karena perilaku merupkan totalitas yang pada orang yang bersangkutan yang terdiri dari tiga tingkat atau ranah yaitu pengetahuan, sikap dan tindakan (Notoatmodjo, 2014).

Berdasarkan analisis bivariat dengan menggunakan uji Chi-square diperoleh nilai $p$-value sebesar 0,037 dimana $(p<0,05)$ sehingga dapat diartikan bahwa terdapat hubungan antara perilaku dengan kejadian DBD. Hal tersebut bertolak belakang dengan penelitian Yayang Hidayatul $\mathrm{N}$ tahun 2018 dengan hasil $\mathrm{p}=0,440 \quad(\mathrm{p}<0,05)$ dimana terdapat tidak ada hubungan antara tindakan responden dengan kejadian DBD di wilayah kerja Puskesmas Papar.

Perilaku dipengaruhi oleh beberapa faktor yaitu faktor predisposisi (faktor yang mempermudah terjadinya perilaku seseorang), faktor pemungkin (faktor yang memungkinkan atau memfasilitasi perilaku), dan faktor penguat (faktor yang pendorong atau memperkuat terjadinya perilaku). Selain pengetahuan, sikap dan tindakan terdapat faktor lain yang mempengaruhi perilaku yaitu ketersediaan fasilitas dan informasi (faktor pemungkin) dan faktor pendorong yang meliputi perilaku tokoh masyarakat, petugas kesehatan, undangundang maupun peraturan baik dari pemerintah pusat maupunpemerintah daerah. Pada penelitian, ditemukan bahwa informasi yang didapatkan oleh masyarakat mengenai penyuluhan penyakit DBD yang kurang menyeluruh dan beberapa desa tidak melakukan PSN secara rutin.

\section{KESIMPULAN}

Jumlah rumah yang positif keberadaan jentik nyamuk sebanyak 20 rumah dengan prosentase 33,3\%. Terdapat hubungan antara keberadaan jentik nyamuk, perilaku PSN dengan kejadian DBD.

\section{SARAN}

Pihak Puskesmas Candi dapat memberikan penyuluhan dalam melakukan PSN serta melakukan kerjasama dengan dinas kesehatan untuk 
melakukan pelatihan kepada masyarakat tentang pencegah dan pemberantasan sarang nyamuk. Masyarakat agar lebih berperan aktif dalam melakukan kerja bakti dan PSN yang diselenggarakan desa.

\section{DAFTAR PUSTAKA}

Depkes RI. (2005). Pencegahan Dan Pemberantasan Demam Berdarah Dengue Di Indonesia. Direktorat Jenderal Penyakit dan Penyehatan Lingkungan.

Hidayatul, Yayang (2018). Hubungan Perilaku dan Kondisilingkungan dengan Kejadian Demam Berdarah Dengue (Studi Wilayah Kerja Puskesmas Papar, Kecamatan Papar, Kabupaten Kediri Tahun 2018).Surabaya:jurusan Kesehatan Lingkungan Poltekkes Kemenkes Surabaya.

Kemenkes RI. 2016. Infodatin 2016 (Situasi Demam Berdarah Dengue di Indonesia). Jakarta: Pengolahan Data dan Informasi, Kementerian Kesehatan Republik Indonesia. Tersedia http://www.depkes.go.id/ download.php?file=download/pusda tin/ infodatin/InfoDatin-2016TB.pdf.

Notoatmodjo, Soekidjo. (2014a). I/mu Perilaku Kesehatan. Jakarta: PT Rineka Cipta.

Notoatmodjo, Soekidjo. (2014b). Metodologi Penelitian Kesehatan. Jakarta: PT Rineka Cipta.

Respati, Yen. K. (2006). Hubungan Perilaku 3M, Abatisasi Dan Keberadaan Jentik Nyamuk Aedes Terhadap Demam Berdarah Dengue. Universitas Airlangga.

Sucipto, Cecep. Dani. (2011). Vektor Penyakit Tropis. Yogyakarta: Gosyen Publishing.

Supardi, S \& Surrahman. (2014).Metodologi

Penelitian.Jakarta.Trans Info Media

Suryanto, H. (2018). Analysis of Behavioral Factors, Use of Gauze, and House Index with The Incidence of DHF in District Dringu Probolinggo. JURNAL KESEHATAN LINGKUNGAN, 10(1), 36-48. 